Studia z etyki i antropologii filozoficznej „Filozofia Chrześcijańska” 18 (2021), s. 129-149

\author{
PRZEMYSŁAW STRZYŻYŃSKI \\ Uniwersytet im. Adama Mickiewicza w Poznaniu \\ Wydział Teologiczny \\ doi: $10.14746 /$ fc.2021.18.7
}

\title{
Propozycja rozwiązania problemu trafu moralnego w kontekście zasady kontroli ${ }^{1}$
}

\section{Wstęp}

Celem artykułu jest przedstawienie zarysu rozwiązania problemu trafu moralnego. Szerszą analizę autor prezentuje w pracy Problem trafu moralnego $w$ kontekście zasady kontroli. Analizy filozoficzno-etyczne ${ }^{2}$. Poniżej prezentowane są najważniejsze idee proponowanego w powyższej książce rozwiązania. Część pierwsza artykułu zawiera wprowadzenie do problemu trafu moralnego i konsekwencji uznania, że przypadek wpływa na ocenę moralną czynów danego podmiotu, a nawet na moralną wartość jego samego. Część druga, z konieczności bardziej obszerna, przedstawia proponowane rozwiązanie problemu trafu moralnego.

\section{Problem trafu moralnego}

Według Thomasa Nagela, jednego z głównych propagatorów szczęścia moralnego, można powiedzieć, że szczęście moralne: „Gdy działanie w istotny sposób zależy od czynników, na które działający nie ma wpływu,

\footnotetext{
1 Artykuł jest zmienionym w niektórych miejscach fragmentem książki autora: P. Strzyżyński, Problem trafu moralnego w kontekście zasady kontroli. Analizy filozoficzno-etyczne, Poznań 2021.

${ }^{2}$ Por. przyp. 1.
} 
a mimo to nie przestaje być dla nas pod tym względem obiektem osądu moralnego, możemy tę zależność określić mianem trafu w życiu moralnym. Może to być traf dobry lub zły"' Tak więc kierowca, który w wyniku zaniedbania prowadzi niesprawny samochód i potrąca dziecko, będzie obwiniany za owo zdarzenie moralnie, mimo że nie miał wpływu na wybiegnięcie dziecka na jezdnię. Zdaniem Nagela:

Kierowca, jeżeli jest całkowicie bez winy, będzie się czuł strasznie z powodu własnej roli w wypadku, ale nie będzie musiał czynić sobie wyrzutów. Dlatego ten przykład żalu podmiotu działającego nie jest jeszcze przypadkiem złego trafu w życiu moralnym. Jeżeli jednak ów kierowca winien jest choćby niewielkiego zaniedbania, na przykład ostatnio nie sprawdzał hamulców, to o ile to zaniedbanie przyczyniło się do śmierci dziecka, nie tylko będzie się czuł okropnie, ale będzie się obwiniał o spowodowanie śmierci. I tu mamy już do czynienia z przykładem trafu w życiu moralnym, bo gdyby nie powstała sytuacja, która wymagała gwałtownego hamowania, by nie najechać na dziecko, musiałby się tylko lekko obwiniać o samo zaniedbanie. Tymczasem zaniedbanie jest identyczne w obu przypadkach, a kierowca nie ma wpływu na to, czy dziecko wybiegnie na drogę czy nie ${ }^{4}$.

Jeśli jednak kierowca bez udziału np. swojej lekkomyślności, niedbalstwa przejedzie dziecko, to nie można tu mówić, zdaniem Nagela, o trafie moralnym $^{5}$. W literaturze najczęściej przyjmuje się podział trafów zaproponowanym przez Nagela:

Po pierwsze, mamy fenomen trafu konstytutywnego - idzie o to, jakim się jest człowiekiem, przy czym nie chodzi o to po prostu, co się rozmyślnie czyni, lecz jakie ma się skłonności, zdolności i temperament. Inną kategorię stanowi traf co do okoliczności - w obliczu jakiego rodzaju trudności i sytuacji stajemy. Dwie następne dotyczą przyczyn i skutków działania - oto jest rzeczą szczęścia, jak jest się w swym działaniu zdeterminowanym przez poprzedzające okoliczności oraz czym kończą się nasze działania lub projekty6.

Wpływ przypadku na moralność, zdaniem Thomasa Nagela i Bernarda Williamsa, widoczny też jest w zdobywaniu wiedzy na jakiś temat. Jest to tzw. traf epistemiczny (ang. epistemic luck). To, co dana osoba wie, zależne jest od wychowania, wykształcenia, które w dużej mierze są niezależne od danego

3 T. Nagel, Traf w życiu moralnym, w: tenże, Pytania ostateczne, thum. A. Romaniuk, Warszawa 1997, s. 39.

${ }^{4}$ Tamże, s. 42.

5 Tamże.

6 Tamże. 
podmiotu. Traf epistemiczny odnosi się też do tego, co wiemy o własnych i cudzych intencjach czy okolicznościach zdarzeń. Jak sądzą zwolennicy trafu moralnego, traf epistemiczny może wpływać na moralny osąd danego działania $^{7}$. O związku trafu z wiedzą pisali też m.in. Harold Ravitch, Richard Foley czy Kenneth W. Kirkwood ${ }^{8}$.

Jeśli więc $\mathrm{w}$ praktyce oceniamy moralnie czyny danego podmiotu, mimo że miał na nie wpływ czynnik będący poza jego wpływem, to właśnie dopuszczamy wpływ przypadku na ową ocenę.

Uznanie słuszności takiego oceniania dla etyki i moralności prowadzi do radykalnych konsekwencji. Kenneth W. Richards podkreśla, że w ocenianiu moralnym kierujemy się zasadą kontroli9. W ujęciu Dany K. Nelkin zasada kontroli pozwala przypisać odpowiedzialność moralną tylko, gdy podmiot miał kontrolę nad działaniem ${ }^{10}$. Tam gdzie na skutki, przyczyny czy okoliczności miał wpływ traf (pojęty jako coś poza kontrolą sprawcy), a sprawca działań zostanie za to osądzony moralnie, pojawia się sprzeczność. $Z$ jednej strony moralnie oceniać można tylko działania będące pod kontrolą działającego, a z drugiej strony oceniamy działania będącego pod wpływem przypadku, czyli czegoś poza kontrolą podmiotu. W debacie na temat trafu moralnego mówi się więc o paradoksie trafu moralnego.

Sprzeczność ta prowadzić może do podważania spójności teorii etycznych zakładających zasadę kontroli. Jak pisze Nagel:

Gdybyśmy konsekwentnie trzymali się warunku panowania nad czynnikami działania, groziłoby to podważeniem większości ocen moralnych, których formułowanie wydaje się nam naturalne. Rzeczy, za które moralnie osądza się ludzi, na więcej sposobów determinuje to, na co nie mają oni wpływu, niż to wynika z naszego początkowego rozeznania. I jeśli wymóg określenia winy i odpowiedzialności, który wydaje się tak naturalny, uwzględni te fakty, to niewiele przedrefleksyjnych osądów moralnych wyjdzie z tego cało. Ostatecznie wydaje się, że nic albo prawie nic z tego, co wiąże się z postępowaniem danej osoby, nie zależy od niej ${ }^{11}$.

${ }^{7}$ A. Schinkel, The Problem of Moral Luck: An Argument Against its Epistemic Reduction, „Ethic Theory and Moral Practice” 2009, nr 12, s. 267-277.

${ }^{8}$ H. Ravitch, Knowledge and the Principle of Luck, ,Philosophical Studies” 30 (1976), s. $347-$ -349; R. Foley, Epistemic Luck and the Purely Epistemic, „American Philosophical Quarterly” 21 (1988), s. 87-97; K.W. Kirkwood, Of Luck Both Epistemic and Moral in Questions of Doping and Non-Doping, „Ethic in Progress” t. 11, 2020, nr 1, s. 77-84.

9 N. Richards, Luck and Desert, w: Moral Luck, red. D. Statman, New York 1993, s. 167.

${ }_{10}$ D.K. Nelkin, Moral Luck, http://plato.stanford.edu/archives/win2013/entries/moral-luck/ [dostęp: 23.02.2021].

${ }_{11}$ T. Nagel, Traf w życiu moralnym..., s. 39. 
Zdaniem Daniela Statmana, jeśli uzna się całkowity wpływ trafu na ludzkie charaktery, uposażenie moralne, okoliczności działań oraz oceny moralne, w konsekwencji trzeba będzie podważyć sensowność przypisywania odpowiedzialności moralnej w ogóle ${ }^{12}$.

\section{Zarys rozwiązania problemu trafu moralnego}

\section{Kontrola w problemie trafu moralnego}

W analizach problemu trafu moralnego, jak pokazano, mówi się o trafie/ /przypadku określanym jako brak kontroli. Sformułowanie to, a też przykłady oddziaływania trafu są jednak niejasne. Za tym stwierdzeniem przemawiają następujące argumenty. Po pierwsze, autorzy nie uznają za przykład oddziaływania trafu na moralność sytuacji, w której sprawca (np. kierowca), bez żadnego wcześniejszego zaniedbania, spożycia alkoholu itp., doprowadza do złego skutku (np. przejeżdża pieszego, który wtargnął na ulicę). Jednocześnie za przykład oddziaływania trafu moralnego autorzy uznają sytuację, w której kierowca przed nieszczęśliwym zdarzeniem dopuścił się jakiegoś zaniedbania. Zaniedbanie, nieprzewidzenie jakiegoś zdarzenia otwierają działania sprawcy na działanie przypadku. Można więc uogólnić, że o trafie moralnym mowa wówczas, gdy między zdarzeniem przypadkowym a działaniami podjętymi przez sprawcę istnieje związek przyczynowy. Nie jest to jednak związek przyczyn i skutków zamierzony i kontrolowany przez sprawcę. Niemniej w pewnej formie inicjowany. Po drugie, Steven Sverdlik słusznie uważa za absurdalne obarczanie kogoś winą czy zasługą moralną, jeśli miałoby to być zależne np. od lotu ptaka, czyli czegoś całkowicie poza kontrolą podmiotu ${ }^{13}$. To skłania do ograniczenia problemu trafu moralnego do tych sytuacji, w których istnieje jednak jakiś rodzaj kontroli podmiotu nad działaniem. Po trzecie, analiza problemu trafu moralnego Michaela Zimmermana postuluje podział na kontrolę ograniczoną i nieograniczoną ${ }^{14}$. Zdarzenia określane jako przykłady trafu moralnego, określa on jako będące pod ograniczoną kontrolą.

${ }^{12}$ D. Statman, Introduction..., w: Moral Luck, red. D. Statman, New York 1993, s. 2-3; B. Williams, Traf moralny, w: tenże, Ile wolności powinna mieć wola?, thum. T. Baszniak, T. Duliński, M. Szczubiałka, Warszawa 1999, s. 217; por. też. P. Strzyżyński, Wybrane konsekwencje trafu moralnego dla etyki, koncepcji społecznych i religijnych, „Teologia i Moralność” 26 (2019), s. 211-233. W książce Problem trafu moralnego w kontekście zasady kontroli... autor prezentuje szerszą gamę konsekwencji całkowitego uznania trafu moralnego. Należą do nich m.in.: krytyka etyki Kanta, podważenie wolności woli, kwestionowanie równej szansy w byciu moralnym dla ludzi.

13 S. Sverdlik, Crime and Moral Luck, w: Moral Luck, s. 181-194.

${ }_{14}$ M.J. Zimmerman, Luck and Moral Responsibility, w: tamże, s. 217-233. 
Zatem sprawca ma jakąś formę kontroli. Po czwarte to, czy coś jest przewidywalne czy nie, może oznaczać też, że jest przewidywalne dla danego podmiotu. Zatem wpływ danego zdarzenia może znaleźć się pod kontrolą podmiotu. Właśnie dzięki wiedzy o tym, co może się stać, mimo że dany podmiot nie inicjuje samego zdarzenia przypadkowego, ma nikłą może, ale jednak kontrolę nad zdarzeniem.

Związek między działaniem sprawcy a działaniem przypadku polega nie tylko na przewidywaniu, ale też np. na zaniedbaniu czy braku przezorności. W tym kontekście postawić można pytanie, czy formą kontroli jest też brak zaniedbania i przewidywanie potencjalnych zdarzeń. Przyjmuje się w tej pracy, za Brianem K. Paynem i Bertramem Gawrońskim, że o kontroli w odniesieniu do ludzkich działań mówić można, gdy działanie jest świadome, dobrowolne, wymagające uwagi i o ograniczonym charakterze ${ }^{15}$. Kontrola może być czynna i bierna. Bierna kontrola polega na świadomości procesów zachodzących w świecie i gotowości (zakładającej możliwość ingerowania w bieg rzeczy) do zmiany stanu rzeczy. Czynna kontrola polegałaby również na inicjowaniu, zatrzymaniu lub zmianie zainicjowanego stanu rzeczy.

Zaniedbanie uznaje się w tym artykule za brak działania, które powinno było nastąpić. Dany sprawca nie wykonał jakieś czynności, co może doprowadzić do niepożądanych skutków. Za Tomaszem z Akwinu należy też przyjąć, że brak działania jest działaniem. Stąd zaniedbanie jest działaniem będącym pod kontrolą danego podmiotu. Element kontroli wynika z samego faktu zaniedbania. Trudno bowiem mówić o zaniedbaniu, jeśli jego brak nie był pod kontrolą sprawcy. Innymi słowy, aby mówić o zaniedbaniu, musi to być czynność świadoma, dobrowolna i wymagająca uwagi. Podobnie przewidywanie potencjalnych oddziaływań przypadkowych ciągów przyczynowo-skutkowych na bieg rzeczy inicjowany przez sprawcę samo w sobie jest działaniem świadomym, dobrowolnym oraz wymagającym uwagi. Świadome, dobrowolne powstrzymanie się od przewidywania, podobnie jak zaniedbanie, jest brakiem działania. Nieprzewidywanie jest więc pod kontrolą podmiotu. Podobnie uważa też Maria Ossowska ${ }^{16}$.

\section{Pojęcie „działań otwierających”}

Wykazano więc, że od strony podmiotowej zarówno zaniedbanie, jak i brak przewidywania są działaniami będącymi pod kontrolą podmiotu. Należy teraz wykazać związek owej kontroli z działaniem przypadku. Samo zaniedbanie

15 B. Payne, B. Gawronski, A history of implicit social cognition: Where is it coming from? Where is it now? Where is it going?, w: Handbook of implicit social cognition: Measurement, theory, and applications, red. B. Gawronski, B. Payne, New York 2010, s. 1-17.

${ }^{16}$ M. Ossowska, Podstawy nauki o moralności, Wrocław-Warszawa-Kraków 1994, s. 213. 
czy brak przewidywania nie są jeszcze inicjowaniem biegu rzeczy, w przeciwieństwie np. do podpalenia domu dziadka czy strzelania do kogoś w celu zabicia. Niemniej, nie są też całkowicie bez związku z biegiem rzeczy. Potencjalny (przypadkowy), niekorzystny bieg rzeczy może nie zaistnieć za sprawą dbałości i przezorności. Mimo że trudno tu mówić wprost o powstrzymaniu czegoś, co się już dzieje (przypadek jest tutaj ciągiem przyczynowo-skutkowym inicjowanym przez inne czynniki niż dany podmiot), to jednak brak zaniedbania, przeciwdziałanie skutkom przypadkowych zdarzeń mają przyczynowy związek z biegiem rzeczy. Wpływają na niego. Zaniedbania czy brak przewidywania są to działania, które nie inicjują ani nie powstrzymują jakiegoś biegu rzeczy tu i teraz, ale inicjują taki stan rzeczy, który jest otwarty w przyszłości na wpływ innych ciągów przyczynowo-skutkowych, niebędących pod kontrolą danego sprawcy. Stąd są one działaniami sprawczymi co do owego otwarcia. Jeśli, jak wykazano, owe zaniechania lub niefrasobliwość są pod kontrolą sprawcy, to inicjowane przez sprawcę otwarcie na przypadek również jest pod jego kontrolą. Zatem nie można mówić, w proponowanych przez zwolenników trafu moralnego przykładach oddziaływania trafu, że dany podmiot nie ma żadnej kontroli nad działaniem. Można uznać, że nie jest ona całkowita, ale jednak jakaś jest.

Rozważane do tej pory przykłady zaniedbania czy niefrasobliwości można potraktować jako przykłady działań otwierających bieg rzeczy na działanie przypadku. Co więcej, można owe działania określić jako właśnie intencjonalnie otwierające inicjowany przez sprawcę bieg rzeczy na korzystne lub niekorzystne działanie przypadku. W skrócie nazwie się te działania, dla potrzeb dalszych analiz, działaniami otwierającymi. Pojęcie działań otwierających nawiązuje do sformułowanej przez Henninga Jensena idei czynu z ograniczoną kontrolą, otwartego na przewidywalne ciągi przyczynowo-skutkowe ${ }^{17}$.

Działania otwierające są działaniami intencjonalnymi i pod kontrolą. Jednocześnie można im przypisać utratę kontroli nad biegiem rzeczy (potocznie mówi się tutaj o zdaniu się na przypadek). Otóż otwarcie biegu rzeczy na oddziaływanie przypadku, o ile było przewidywalne w momencie podejmowania działań otwierających, może być charakteryzowane jako pozbycie się kontroli nad działaniem przypadku. Przy takim sformułowaniu trudno mówić, że przypadek w trafie moralnym polega na braku kontroli, ponieważ jego oddziaływanie jest warunkowane wcześniejszą utratą kontroli przez sprawcę, nad którą to utratą działający miał kontrolę. Przypadek w trafie moralnym nie jest zatem całkowicie poza kontrolą sprawcy. $Z$ drugiej strony ciąg przyczynowo-skutkowy nakładający się na otwarty przez sprawcę bieg rzeczy nie jest pod kontrolą sprawcy. Ciąg ten jest również warunkiem koniecznym

${ }^{17}$ H. Jensen, Morality and Luck, w: Moral Luck, s. 131-133. 
owych nieszczęśliwych lub szczęśliwych nałożeń się tych dwóch ciągów przyczyn i skutków. Skutek owego nałożenia się jest wypadkową dwóch ciągów przyczynowo-skutkowych.

Poza tym, jeżeli działanie pijanego/niedbałego kierowcy (przykład Michaela Otsuki), który przypadkiem powoduje katastrofalne osuwisko, uznać za działanie nieobciążone winą moralną, to nie każde przypadkowe nałożenie się ciągu przyczynowo-skutkowego na otwarty przez sprawcę bieg rzeczy da się zakwalifikować jako przykład trafu moralnego ${ }^{18}$. Nie można więc powiedzieć, że traf moralny oddziałuje całkowicie poza kontrolą sprawcy ani też, że wszelkie będące pod kontrolą sprawcy otwarcia potencjalnych biegów rzeczy są wystarczającą podstawą do przypisania winy moralnej. Między otwarciem przyczynowym a przypadkiem musi zaistnieć jeszcze powiązanie. Przyjmuje się tutaj, że owym łączącym elementem jest obiektywna podmiotowa zdolność do przewidzenia owego nałożenia się łańcuchów przyczynowo-skutkowych. $\mathrm{O}$ trafie moralnym powinno się więc mówić w sytuacjach, w których podmiot może przewidzieć nałożenie się potencjalnych ciągów przyczyn i skutków na bieg rzeczy inicjowany przez ów podmiot. Samo nałożenie się owych ciągów nie jest zależne od danego sprawcy. Na tym polega właśnie działanie przypadku. Niemniej to, że ów potencjalny ciąg może oddziaływać na bieg rzeczy inicjowany przez dany podmiot, jest zależne od podmiotu, o ile oczywiście obiektywnie i podmiotowo mógł takie oddziaływanie przewidzieć i jemu zapobiec. Z powyższego wynika również, że nie można w problemie trafu moralnego mówić o całkowitym braku kontroli sprawcy nad tym, czy i jak oddziałuje przypadek. W konsekwencji nie można mówić o braku odpowiedzialności podmiotu. Jak zostanie wykazane niżej, powyższe uwagi każą modyfikować też sformułowanie tzw. paradoksu trafu moralnego.

Wprowadzenie pojęcia działań otwierających pozwala też wyjaśnić różnicę między rodzajami trafu moralnego, które wyróżnił Nagel. Otóż o kontroli nad działaniem w wypadku działań otwierających można, zgodnie z przyjętym rozumieniem kontroli, mówić wówczas, gdy podmiot świadomie i dobrowolnie inicjuje owo otwarcie. Tak dziać się może w wypadku trafu okoliczności, skutku i przyczyny. W wypadku natomiast trafu konstytutywnego trudno mówić o działaniach otwierających z tej racji, że podmiot nie ma, jako dziecko, świadomości ani dobrowolności wystarczającej do mówienia o działaniach otwierających. Wpływ rodziny, środowiska społecznego czy genotypu na charakter czy moralne uposażenie dziecka są więc całkowicie poza jego kontrolą. O możliwej kontroli, w postaci zmiany skutków oddziaływania trafu konstytutywnego można mówić dopiero wtedy, kiedy podmiot zauważy skutki owego oddziaływania i potrafi je modyfikować. Zachodzi tutaj przy tym koniunkcja

${ }^{18}$ M. Otsuka, Moral Luck: Optional, Not Brute, ,Philosophical Perspectives” 23 (2009), s. 381. 
owych warunków. Sama świadomość, np. uwarunkowania własnego uposażenia moralnego bez możliwości jego modyfikowania, nie pozwala na przypisanie podmiotowi kontroli, zatem też odpowiedzialności.

\section{Zagadnienie tzw. paradoksu trafu moralnego}

Stosując pojęcie działań otwierających, można też przeformułować problem trafu moralnego w następujący sposób: przypisuje się odpowiedzialność moralną, winę lub zasługę sprawcy, który swoim kontrolowanym działaniem otworzył bieg rzeczy prowadzący do nałożenia się na ów bieg rzeczy ciągu przyczynowo-skutkowego (będącego poza bezpośrednią kontrolą podmiotu), co doprowadziło do jakiejś szkody (lub pożytku). Chodzi o takie nałożenie się ciągów, że wynikiem tego jest zdarzenie, które nie zaistniałoby bez owych nakładających się ciągów przyczyn i skutków. Otwarcie przez sprawcę ciągu zdarzeń uznać można za konieczny, ale nie wystarczający warunek skutku. Należy w konsekwencji postawić pytanie, czy przy takim sformułowaniu problemu trafu moralnego można mówić o paradoksie uderzającym w pojęcie moralnej odpowiedzialności i sensowność jej stosowalności, co - jak pokazano - rozważał Nagel.

Paradoks trafu moralnego można przedstawić następująco:

Tw. 1. Przypisuje się odpowiedzialność moralną wówczas, gdy sprawca miał kontrolę nad biegiem rzeczy.

Tw. 2. Przypadek oddziałuje tak, że sprawca nie ma kontroli nad biegiem rzeczy, a mimo to przypisuje się jemu odpowiedzialność moralną.

W: Zatem przypisuje się odpowiedzialność moralną, gdy sprawca miał kontrolę nad biegiem rzeczy i gdy jej nie miał.

Stosując pojęcie działań otwierających w wypadku trafów okoliczności, przyczyny i skutku, tw. 2. można przeformułować tak:

Przypadek oddziałuje tak, że sprawca nie ma bezpośredniej kontroli nad nałożeniem się ciągu przyczynowo-skutkowego na bieg rzeczy, otwarty na ów ciąg przez działania będące pod kontrolą sprawcy.

Paradoks brzmiałby wówczas: Mimo uznania, że warunkiem przypisania odpowiedzialności i winy/zasługi moralnej jest kontrola nad działaniem, sprawcy przypisuje się winę/zasługę za niebędące pod jego bezpośrednią kontrolą nałożenie się ciągu przyczynowo-skutkowego na taki bieg rzeczy, którego zaistnienie było pod kontrolą sprawcy. Ów bieg rzeczy przy tym jest warunkiem koniecznym, ale nie wystarczającym skutku nałożenia się dwóch ciągów przyczynowo-skutkowych.

Na podstawie takiego sformułowania można dojść do wniosku, że paradoks nie jest już tak paradoksalny, gdyż element kontroli jednak istnieje po 
stronie sprawcy. Paradoksalne przypisanie odpowiedzialności moralnej dotyczyłoby tylko owego nałożenia się ciągu przyczynowo-skutkowego, który jest pod bezpośrednią kontrolą sprawcy. Ponieważ jednak sprawca nie inicjuje tego ciągu i nie jest za niego bezpośrednio odpowiedzialny, trudno przypisywać jemu odpowiedzialność moralną związaną z działaniem intencjonalnym i będącym pod jego kontrolą. Można jemu przypisać jedynie odpowiedzialność za zaniedbania czy też niefrasobliwość.

W wypadku trafu konstytutywnego można go wyrazić następująco (Sformułowanie 1.): przypisuje się odpowiedzialność moralną, winę lub zasługę sprawcy, który swoim całkowicie niekontrolowanym działaniem „otworzył” własną osobowość na działanie ciągu przyczynowo-skutkowego, co skutkuje takimi, a nie innymi, skłonnościami charakteru i uposażeniem moralnym.

W świetle poprzednich analiz w wypadku trafu konstytutywnego można przeformułować tw. 2.: Przypadek oddziałuje tak, że sprawca swoim całkowicie niekontrolowanym działaniem otworzył własną osobowość na działanie ciągu przyczynowo-skutkowego, co skutkuje takimi, a nie innymi, skłonnościami charakteru i uposażeniem moralnym, a mimo to przypisuje się jemu odpowiedzialność moralną.

W tym sformułowaniu paradoks nadal byłby paradoksem.

Zakładając obowiązywanie zasady kontroli [dalej: ZK], uznaje się w tym artykule, że przypisanie owej odpowiedzialności w wypadku powyższego sformułowania paradoksu trafu konstytutywnego jest absurdalne, gdyż „sprawca” początkowo nie ma kontroli nad tworzącym się w nim charakterem, nad posiadanym genotypem czy nad wzorcami osobowymi, z którymi ma styczność. W związku z tym takowego paradoksu nie ma.

Kontrola podmiotu nad skutkami działania trafu konstytutywnego staje się możliwa dopiero wówczas, gdy podmiot osiągnie świadomość jego działania i możliwość wpływu na jego skutki. Stąd wprowadza się tutaj drugie sformułowanie paradoksu trafu konstytutywnego.

(Sformułowanie 2.): W wypadku trafu konstytutywnego przypisuje się odpowiedzialność moralną, winę lub zasługę sprawcy, który swoim kontrolowanym działaniem zmienił lub nie, skutki oddziałującego w przeszłości na jego osobowość ciągu przyczynowo-skutkowego, będącego w momencie oddziaływania całkowicie poza kontrolą sprawcy.

W tym wypadku można następująco przeformułować tw. 2.: Przypadek oddziałał na osobowość podmiotu, który swoim kontrolowanym działaniem zmienił lub nie, skutki oddziałującego w przeszłości na jego osobowość ciągu przyczynowo-skutkowego, będącego w momencie oddziaływania całkowicie poza kontrolą sprawcy, a mimo to przypisuje się jemu odpowiedzialność moralną.

W tym sformułowaniu ponownie nie ma paradoksu, gdyż podmiot ma kontrolę (wtórną) nad zmianą skutków oddziaływania przypadku w przeszłości 
i słusznie może być za to moralnie oceniany. Nie można więc mówić o przypisaniu odpowiedzialności moralnej mimo braku kontroli. Natomiast gdyby miał być oceniany za to, nad czym nie ma kontroli, podobnie jak w sformułowaniu 1. , byłoby to absurdalne.

Powyższe analizy pozwalają stwierdzić, że przedstawione przez Nagela i Williamsa przykłady trafu moralnego zawierają w sobie element kontroli w postaci działań otwierających oraz, w wypadku trafu konstytutywnego, możliwości wtórnej i częściowej kontroli nad osobowością i uposażeniem moralnym. Jak widać, sformułowania paradoksu trafu moralnego okazują się albo mniej paradoksalne, albo w ogóle paradoksalne nie są.

\section{Zagadnienie skutku i intencji w kontekście dzialań otwierających}

W problemie trafu moralnego w ujęciu Nagela i Williamsa ważną rolę odgrywają skutki działań. Autor prezentowanych rozważań postuluje rozwiązanie problemu trafu moralnego $\mathrm{z}$ uwzględnieniem również intencji sprawcy. Poniżej zostaną przedstawione oba owe zagadnienia w kontekście działań otwierających.

W wypadkach trafu okoliczności, przyczyny czy skutku różnica w postulowanej ocenie moralnej dotyczy sytuacji z kontrolą ograniczoną, ale otwartą na przewidywalne ciągi przyczynowo-skutkowe. Między przykładowymi kierowcami przypadek powoduje tę różnicę, że w wypadku nieszczęśliwego kierowcy zdarzenia przez niego nieinicjowane (wbiegnięcie dziecka, pieszego) nakładają się na inicjowany jego zaniedbaniem ciąg zdarzeń. W wypadku szczęśliwego kierowcy nie dochodzi do takiego nałożenia się ciągów przyczyn i skutków. Przypadek czyni różnicę $\mathrm{w}$ realnie zaistniałych zdarzeniach. Obaj kierowcy nie mają wpływu na to, czy ktoś zainicjuje wbiegnięcie pod koła ich samochodów czy nie. Zapytać tutaj trzeba, czy to wystarczy do różnej oceny moralnej obu kierowców. Samo wbiegnięcie było poza ich kontrolą (inicjowanie lub powstrzymanie), ale otwartość ich działań na niekorzystne skutki owego wbiegnięcia było jednak pod ich kontrolą. Odpowiadając na to pytanie, należy wpierw ustosunkować się do kilku prób odpowiedzi udzielanych przez innych autorów.

Judith Andre, podobnie jak Nicholas Rescher czy Norvin Richards są zwolennikami moralnego oceniania przede wszystkim cech charakteru, stąd nie widzą powodu, żeby różne skutki działań osób o tym samym charakterze, intencjach (czy tej samej wartości moralnej) mogły być powodem zmiany owej oceny ${ }^{19}$. Jednakże skutki działań otwierających są nieraz bardzo poważne.

19 J. Andre, Nagel, Williams, and Moral Luck, w: Moral Luck, s. 123-129; N. Rescher, Moral Luck, w: tamże, s. 141-166; N. Richards, Luck and Desert, w: tamże, s. 167-180. 
Poza tym łączą się z podmiotem, gdyż nie są całkowicie poza jego kontrolą. Skutku działań otwierających nie można oddzielić od podmiotu, gdyż może to podpadać pod zarzut ignorowania spójności podmiotu z jego działaniami. Stąd też przyjmuje się w tym artykule, że w ocenie moralnej czynu należy wziąć pod uwagę skutki działań otwierających, aby nie spotkać się z zarzutem ignorowania ważnego elementu rzeczywistości oraz spójności podmiotu.

Należy też stwierdzić, że uznanie roli skutków w ocenie moralnej otwiera moralność na działanie przypadku, ale bez negacji ZK. Więcej nawet, przypisanie odpowiedzialności za skutki działań otwierających zakłada częściową kontrolę podmiotu nad tymi działaniami.

Nie można więc zgodzić się z postulatem, że traf jedynie ujawnia wady charakteru jako przyczynę działań otwierających. Co więcej, cechy te mogą być jawne samemu sprawcy, po jego namyśle nad wadliwością działań otwierających, bez zaistnienia nieszczęśliwego przypadku. Traf nie jest tutaj konieczny, ale może okazać się pomocny.

Z kolei, z możliwym poglądem, że wina moralna tkwi już w zainicjowaniu owej otwartości, a przypadek niczego nie zmienia w ocenie danego podmiotu, można zgodzić się tylko częściowo. Wydaje się, że ignorowanie skutków działań otwierających oraz niezróżnicowanie w ocenie moralnej zdarzeń o różnych realnych skutkach jest dosyć kłopotliwe. Pojawia się tutaj bowiem wątpliwość, skoro obaj niedbali kierowcy byliby tak samo winni (za sprawą inicjowania owej otwartości), to bez względu na jakiekolwiek skutki realne. Winniśmy więc obwiniać ich tak samo bez względu na skutki działań lub tak samo ze względu na potencjalne skutki działań. W pierwszym wypadku ignoruje się to, co się realnie wydarzyło. W drugim, mnożenie potencjalnych skutków działań kazałoby obwiniać za zdarzenia, które realnie jeszcze nie zaistniały. Tak więc zwolennicy poglądu, że traf tylko ujawnia cechy charakteru, musieliby dopuścić do potencjalnego obwiniania danej osoby za zdarzenia niezaszłe, za niemal wszelkie prawdopodobne skutki działań oparte na charakterze sprawcy. To jest jednak absurdalne. W ocenie moralnej lepiej jest brać pod uwagę skutki działań otwierających niż wszelkie potencjalne skutki czyjegoś charakteru.

Przedstawione wyżej analizy każą uwzględniać nie tylko skutek działań otwierających. Wskazują też, że w analizie problemu trafu moralnego należy brać pod uwagę intencję osoby działającej. Działanie otwierające w postaci zaniedbania, braku przewidzenia itp. jest jednak działaniem intencjonalnym w tym znaczeniu, że ma jakiś cel. Wykazano też, że działania otwierające są świadome, dobrowolne oraz wymagają uwagi. W wypadku zaniedbania czy braku przezorności intencją może być choćby niechęć do podjęcia jakiegoś wysiłku czy też chęć zrobienia czegoś innego zamiast czynności zapobiegającej itp. Jak słusznie jednak pisze Jensen, w wypadku niedbałego kierowcy, 
który przejechał dziecko, niedbalstwo było intencjonalne, ale przejechanie dziecka już nie ${ }^{20}$. Jak można wnioskować, sam skutek nie wskazuje na intencjonalność działań. Jeśli z kolei intencjonalność, jako wskaźnik wolitywnego działania, potraktować jako ważny warunek przypisania odpowiedzialności i winy moralnej, to faktycznie trudno obwiniać kierowcę za nieintencjonalne spowodowanie wypadku.

Pogląd Jensena kazałby nie przypisywać intencjonalności skutkom działań otwierających, a jedynie samym tym działaniom (np. zaniedbaniu). Dotykamy tutaj zagadnienia zakresu czyichś intencji, w tym tego, czy niedbałemu kierowcy można przypisać intencję skrzywdzenia pieszego. Wiele zależy od tego, co przez intencje się rozumie. Jeśli, jak pokazano, rozumieć je jako pragnienie jakiegoś stanu rzeczy, to przejechanie dziecka (jako potencjalny skutek działań otwierających) nie musi być w zakresie intencji sprawcy działań otwierających (np. zaniedbania). Jeśli jednak intencje rozumieć jako wnioski rozumowania praktycznego, jak sugeruje jedno $\mathrm{z}$ ich ujęć, to o ile podmiot wnioskuje o możliwym nieszczęśliwym zdarzeniu, staje się ono jego intencją, mimo że niechcianą. Problem jest też o tyle złożony, że sam podmiot może mieć trudność z określeniem, co jest jego intencją. Bywa też, że podmiot oszukuje sam siebie co do prawości czy treści własnych intencji. Potraktowanie jednak intencji jako wniosków rozumowania praktycznego kazałoby przypisać charakter intencji wszelkim możliwym i pomyślanym przez działający podmiot konsekwencjom jego działań. To już podważa sensowność takiego traktowania intencji podmiotu, gdyż istnieje przecież różnica między przewidywanymi a zamierzonymi skutkami działań ${ }^{21}$. Zamiar łączy się z pragnieniem danego skutku. Zazwyczaj też intencjom przypisuje się pragnienie skutku i zakłada się ich świadomość. Takie też rozumienie tutaj się przyjmuje. Zatem o ile podmiot nie pragnie nieszczęśliwego lub pomyślnego zdarzenia, nie jest ono jego intencją. Podobnie więc jak Jensen, intencje danego działania otwierającego ogranicza się w tej pracy do samego działania otwierającego, a nie jego skutków, o ile podmiot nie miał np. intencji, aby za sprawą przypadku osiągnąć jakiś skutek. Z kolei z tej racji, że intencja czynu jest najbardziej wewnętrznym, związanym ze świadomością i wolą, elementem spośród branych zazwyczaj w moralnej ocenie czynu, przyjmuje się w tej pracy, że to właśnie intencja decydować będzie o przypisaniu winy bądź zasługi moralnej.

W myśl sformułowań trafu moralnego nałożenie się ciągu przypadkowego na działania otwierające nie jest intencjonalne. Nie jest zatem celowym działaniem sprawcy, nakierowanym na wyrządzenie szkody lub jakiegoś

${ }^{20}$ H. Jensen, Morality and Luck..., s. 135.

${ }^{21}$ Tomasz z Akwinu, Suma teologiczna, tłum. F.W. Bednarski, Londyn 1970, t. 18, II-II, q. 64, a 7, s. 73 . 
pożytku. Gdyby tak było, że dany podmiot celowo pozostawia jakiś otwarty ciąg przyczynowy i liczy, że przypadek dokończy złego/dobrego dzieła, sprawca byłby, zgodnie uznaną $\mathrm{w}$ tej pracy rolą intencji, niewątpliwie bardziej winny lub godny pochwały. Jego związek z biegiem rzeczy byłby większy o element intencji, niż w wypadku przykładowego sprawcy z problemu trafu moralnego, mimo że obaj nie mieli pełnej kontroli nad skutkiem swoich działań.

Zwrócenie uwagi na intencje sprawcy utrudnia jednak ocenę moralną. Intencja nie jest bowiem wprost widoczna dla osób oceniających działanie danego podmiotu. Sam podmiot również nie zawsze zdaje sobie sprawę $\mathrm{z}$ własnych intencji. Stąd trudność w jednoznacznym przypisaniu winy moralnej. Rola intencji okaże się też kluczowa w przedstawionej poniżej próbie odpowiedzi na problem trafu moralnego.

\section{Zagadnienie odpowiedzialności moralnej sprawcy dzialań otwierających jako kluczowe dla rozwiązania problemu trafu moralnego}

Aby dojść do rozwiązania trafu moralnego, należy przedstawić proponowane rodzaje przypisania odpowiedzialności i winy/zasługi moralnej w zależności od różnych działań podmiotu i ich skutków, z uwzględnieniem roli przypadku i działań otwierających.

Za takimi autorami jak Edmund Husserl czy Wilhelm Wieschedel przyjmuje się tutaj, że ludzka świadomość jest intencjonalna oraz responsywna. W efekcie uznać należy, że fundamentem odpowiedzialności, w tym moralnej, jest odpowiedzialnościowość jako wyprzedzające wszelkie działanie nastawienie ku światu ${ }^{22}$.

W analizie zakresu odpowiedzialności sprawcy działań otwierających ważne jest pytanie, czy ponosi on całkowitą odpowiedzialność za skutek nałożenia się dwóch ciągów przyczynowych. Skutek ma tutaj bowiem dwa warunki konieczne, z których jeden tylko jest pod kontrolą sprawcy. Drugiego ciągu (przypadkowego) on nie inicjuje. Przypisanie jemu całkowitego sprawstwa nie jest więc możliwe. Stąd ewentualna ocena moralna działań otwierających powinna brać to pod uwagę.

Ponieważ w wypadku trafu moralnego, jak pokazano, zakłada się częściową kontrolę podmiotu nad tym, co się dzieje, nie można mówić tylko o odpowiedzialności sprawczej. $Z$ tej racji, że działania otwierające są działa-

${ }^{22}$ Zob.: W. Weischedel, Das Wesen der Verantwortung, Frankfurt am Main 1972³, s. 17 za: J. Filek, Filozofia odpowiedzialności XX wieku, Kraków 2003, s. 142. 
niami świadomymi i spełniają ZK, sprawca tych działań ponosi też odpowiedzialność moralną.

Ponieważ z kolei otwarcie ciągu na działanie przypadku jest konsekwencją moralnej odpowiedzialności i winy (w postaci zaniedbania czy świadomego nieprzewidzenia), należy -jak się tu przyjmuje - przenieść ten rodzaj powiązania podmiotu ze zdarzeniem również na skutki owego otwarcia. Skoro działania w postaci np. zaniedbania są powodem przypisania moralnej odpowiedzialności, a co do tego zgodni są chyba wszyscy, to skutki tego otwarcia biegu rzeczy na działanie przypadku winny też stać się racją przypisania odpowiedzialności moralnej. $\mathrm{O}$ ile jednak nie ma intencji doprowadzenia do złego skutku, nie można przypisać winy moralnej. Powyższe zakłada, jak widać, możliwość przypisywania moralnej odpowiedzialności bez przypisania winy moralnej. Nie można natomiast przypisać winy bez przypisania odpowiedzialności zarówno kauzalnej, jak i moralnej.

Pogląd właśnie przedstawiony różni się od tradycyjnego utożsamienia odpowiedzialności moralnej z moralną winą, co czyni się zazwyczaj w taki sposób, że przypisanie odpowiedzialności moralnej jest równoznaczne z przypisaniem winy. Jednakże również Benjamin C. Zipursky odróżnia dwa wymiary w odpowiedzialności za dany czyn: odpowiedzialność wyrażającą winę (ang. faultexpresing responsibility), która próbuje wyrazić stopień związku działania z charakterem sprawcy; oraz odpowiedzialność za sprawstwo (ang. angency-linking resposnsibility), która „mówi, że stopień w jakim dana osoba jest odpowiedzialna za jakieś zdarzenie, zależy od tego, czy dane zdarzenie, czynność jest danej osoby"23. Z kolei Andre odróżnia odpowiedzialność jako zobligowanie do naprawy krzywdy od odpowiedzialności jako bycia godnym kary lub pochwały. Z tekstu Andre wynika też, że ta druga odpowiedzialność tożsama jest z przypisaniem winy lub zasługi moralnej. Odpowiedzialność jako zobligowanie do naprawy krzywdy z winą moralną nie jest tożsama. Autorka ta wprowadza też odróżnienie bycia wartym naśladowania od bycia wartym moralnej pochwały oraz moralnej oceny danej osoby od przypisania winy. Można, jej zdaniem, kogoś nazwać złym, ale nie winnym, albo też winnym, ale nie złym ${ }^{24}$. Korzystając z uwag Zipurskiego, Andre, a także Anny Krajewskiej, przyjmuje się tutaj odróżnienie odpowiedzialności moralnej jako wzywającej do zadośćuczynienia od odpowiedzialności moralnej jako implikującej winę lub zasługę moralną 25 . Dystynkcja ta zostanie zastosowana jako pomocna w przedstawieniu propozycji rozwiązania problemu trafu moralnego,

${ }^{23}$ B.C. Zipursky, Two dimensions of responsibility in crime, tort, and moral luck, „Theoretical Inquiries in Law" 9 (1), 2008, s. 99.

24 J. Andre, Nagel, Williams, and Moral Luck, s. 126.

${ }^{25}$ A. Krajewska, Problem odpowiedzialności za przypadkowe skutki działań, „Roczniki Filozoficzne” LXVII (2019), nr 2, s. 119-140. 
przy czym uprości się tutaj nazewnictwo. Odróżniane będą wobec tego odpowiedzialność moralna oraz wina/zasługa. Zakłada się więc, że można nie być moralnie winnym, a być moralnie odpowiedzialnym za naprawę jakieś sytuacji. W wypadku działań otwartych na wpływ przypadku, bo o takich działaniach mowa w problemie trafu moralnego, za powyższym zróżnicowaniem przemawia odróżnienie działań otwierających, które były bez intencji wyrządzenia zła lub dobra i bez związku z powstałym skutkiem (np. pijany kierowca powodujący lawinę), od działań otwierających, które miały zły lub dobry skutek oraz od działań otwierających z intencją doprowadzenia do skutku dobrego lub złego. Przyjęte przed chwilą dystynkcje pojęciowe pozwolą zróżnicować ocenę moralną owych odmiennych sytuacji. Próbuje się tutaj uzgodnić możliwe stany faktyczne, wynikające $\mathrm{z}$ interakcji przypadku $\mathrm{z}$ ludzkim działaniem, z elementami tradycyjnie stosowanymi w ocenie moralnej danego działania. Zgodnie z poprzednimi ustaleniami w owym uzgodnieniu kluczowym elementem okaże się intencja.

Pamiętając, że mowa tutaj o braku bezpośredniej kontroli nad skutkiem oddziaływania przypadku oraz o posiadaniu umiejętności przewidzenia nałożenia się na działania otwierające przypadkowego zdarzenia, przedstawić można następujące powiązania działań otwierających z ocenami moralnymi.

Brak odpowiedzialności moralnej, bez winy/zasługi, za skutki działań otwierających występuje wówczas, gdy zachodzą czynności otwierające, które są warunkiem koniecznym zaistnienia skutku przypadkowego, skutek ów nie zaistniał, a sprawca nie miał złej/dobrej intencji co do skutku przypadkowego.

Brak odpowiedzialności moralnej, bez winy/zasługi, ale z pogorszeniem/ /polepszeniem wartości moralnej podmiotu za skutki działań otwierających występuje wówczas, gdy zachodzą czynności otwierające, które są warunkiem koniecznym zaistnienia skutku przypadkowego, skutek ów nie zaistniał, a sprawca miał złą/dobrą intencję co do skutku przypadkowego.

O odpowiedzialności moralnej, bez winy/zasługi, za skutki działań otwierających można mówić, gdy zachodzą czynności otwierające, które są warunkiem koniecznym zaistnienia skutku przypadkowego, skutek ów zaistniał, a sprawca nie miał złej/dobrej intencji co do skutku przypadkowego.

Z kolei o odpowiedzialności moralnej z przypisaniem winy/zasługi mówić można, gdy zachodzą czynności otwierające, które były warunkiem koniecznym zaistniałego skutku przypadkowego, a sprawca miał złą/dobrą intencję co do skutku przypadkowego. Podobna odpowiedzialność zachodzi przede wszystkim we wszelkich działaniach, w których sprawca bez oddziaływania przypadku, przy zachowaniu warunków przypisania odpowiedzialności moralnej, doprowadza do jakiegoś skutku.

W powyższych sytuacjach podmiot jest oczywiście odpowiedzialny moralnie oraz winny/zasługujący za same działania otwierające. O pełnej odpowie- 
dzialności i winie/zasłudze można mówić tylko w wypadku działania z całkowitą kontrolą i z intencją złą/dobrą. Można też wtedy mówić o pogorszeniu lub polepszeniu wartości moralnej podmiotu.

Proponowane, na podstawie dystynkcji Andre, odróżnienie odpowiedzialności od winy boryka się z pewnym problemem. Czym bowiem różni się przypisanie odpowiedzialności moralnej i winy od przypisania samej odpowiedzialności moralnej? Jako odpowiedź proponuje się tutaj, co następuje. Odpowiedzialność moralna, za sprawą odpowiedzialności kauzalnej, czyni podmiot sprawcą lub częściowym sprawcą skutku danego zdarzenia. Odpowiedzialność moralna oznacza jednak takie powiązanie, które w wypadku wyrządzonych szkód nakazuje ich naprawę. W wypadku skutków dobrych trudno mówić o jakiejś konieczności restytucji stanu rzeczy sprzed szkody, dlatego że stan rzeczy nie wymaga takowej naprawy, a jedynie kontynuacji jego istnienia. Odpowiedzialność w tym wypadku miałaby więc inny charakter niż naprawczy.

Przypisanie winy mówi z kolei o pogorszaniu się wartości moralnej danego podmiotu. Wskazuje bowiem na złą intencję jako dopuszczającą się (jak w wypadku trafu moralnego) pewnego zaniedbania czy stworzenia ryzyka. Nie dotyczy jednak skutku działań otwierających, o ile podmiot i co do tego nie miał złej intencji. Symetrycznie przypisanie zasługi moralnej nie następuje bez dobrej intencji, która działanie otwierające traktuje jako szansę na osiągnięcie dobrego skutku pod wpływem trafu czy - szerzej - czynników od podmiotu nie do końca zależnych.

Proponowane rozwiązanie, jak widać, nie niweluje wpływu przypadku na przypisanie odpowiedzialności moralnej. Przypadek nie ma natomiast wpływu na przypisanie winy/zasługi moralnej, gdyż to zależy od tego, jakie sprawca miał intencje. Stąd przyjmuje się tutaj, że przypadek (traf okoliczności, skutku i przyczyny) wprowadza różnicę w ocenie moralnej działań sprawcy, o ile ów wpływ był wynikiem działań otwierających sprawcy.

\section{Traf konstytutywny a odpowiedzialność moralna, wina i zasługa}

Powyżej przedstawiono propozycję rozwiązania problemu trafu moralnego w kontekście przede wszystkim trafów okoliczności, przyczyny i skutku. W wypadku trafu konstytutywnego podmiot staje się dopiero wtedy odpowiedzialny moralnie, gdy ma świadomość swoich cech charakteru i osobowości oraz wie, jak je zmienić. Ostatni warunek zakłada, że zmiana taka jest w wypadku danego podmiotu możliwa. Brak podjęcia prób owej zmiany można potraktować jako zgodę na wpływ tego, co było poza kontrolą podmiotu, a uwarunkowało jego moralne inklinacje. Pod takimi warunkami działania podmiotu mogą podlegać ocenie moralnej. 
Jeżeli uznać wrodzoną ludziom responsywność jako podstawę również odpowiedzialności moralnej, to podmiot o normalnie funkcjonującej osobowości jest niejako skazany na bycie odpowiedzialnym za to, jakim jest. Mimo więc że można nie wiedzieć, jak się zmienić, winno się tej wiedzy poszukiwać. Wobec tego podmiot jest odpowiedzialny moralnie za niepoprawione efekty trafu konstytutywnego, o ile miał świadomość owych efektów. Staje się też winny, jeżeli zaniecha owej zmiany po poznaniu drogi do tego wiodącej.

Inaczej dzieje się wówczas, gdy konstytutywne uwarunkowania nie dadzą się zmienić. Zgodnie z ZK nie można jemu przypisać sprawstwa tam, gdzie działa niezmienialne uwarunkowanie psychiczne czy społeczne. W wypadku złych działań uwarunkowanych tak ściśle podmiot może odczuwać żal i winę. Poczucia te niekoniecznie świadczą o realnej winie moralnej czy też moralnej odpowiedzialności ${ }^{26}$.

Odpowiedzialnym i winnym moralnie byłby podmiot, gdyby wiedząc, jak się zmienić, zaniechał tego, czyli zgodził się na oddziaływanie moralnie niewłaściwej swojej cechy. Winę możnaby przypisać z tej racji, że takie zaniechanie uznać można za działanie intencjonalne, a zgodę na brak poprawy za przejaw złej intencji. W tym kontekście zgodzić się można ze zgłoszonym przez Roberta M. Adamsa postulatem powinności brania odpowiedzialności za własne stany mentalne ${ }^{27}$. Nie można natomiast zgodzić się z poglądem, że należy obwiniać czy nawet karać za każdy taki stan. Autor artykułu uznaje bowiem, że stany mentalne mogą być pochodną czynników bezpośrednio przez podmiot niekontrolowanych. Dopiero ich uświadomienie sobie pozwala na osiągnięcie kontroli nad nimi.

\section{Zakończenie}

We wstępie do artykułu wyliczono kilka podstawowych zagadnień wiążących się z problemem trafu moralnego. Pora więc zamknąć klamrą ten artykuł i udzielić odpowiedzi na owe zagadnienia na postawie przedstawionych analiz.

W artykule wykazano, że nie ma podstaw do mówienia o paradoksalności w problemie trafu moralnego. W wypadku działań otwierających (w wypadku trafów okoliczności, przyczyny i skutku) istnieje kontrola podmiotu nad owymi działaniami. Jednocześnie nie są przykładami oddziaływania owych trafów zdarzenia bez związku np. z nieprzewidzeniem czy zaniedbaniem.

${ }^{26}$ S. Wolf, The Moral of Moral Luck, „Philosophic Exchange” 31 (2001), s. 13-14; por. P. Strzyżyński, Kilka uwag na marginesie sporu między Gregorym S. Kavka a Williamem Neblettem o poczucie winy, „Ruch Filozoficzny” 72 (2016), nr 2, s. 63-76.

27 R.M. Adams, Involuntary Sins, ,The Philosophical Review” 94 (1985), s. 13. 
Oznacza to, że w problemie trafu moralnego mowa jest wyłącznie o działaniach otwierających, które zawierają element kontroli. Nie można więc zbudować paradoksu, gdyż element kontroli jest zachowany, choć w różnym stopniu zarówno w intuicji brania pod uwagę $\mathrm{ZK}$, jak i oceniania zdarzeń pod wpływem przypadku.

Podobnie w wypadku trafu konstytutywnego można mówić o częściowej kontroli nad uwarunkowaniami dzięki ich uświadomieniu sobie i wykorzystaniu mechanizmów własnej psychiki. W tej części natomiast, w której nie można dokonać zmiany, konsekwentnie nie powinno się mówić o kontroli danego podmiotu. W tym wypadku nie powinno się też przypisywać odpowiedzialności moralnej czy też winy/zasługi.

Z paradoksalności powstającej pod wpływem przypadku wynikać miało podważenie podstaw przypisywania odpowiedzialności i winy moralnej. Ponieważ paradoksalność została podważona, można tym samym zanegować owe konsekwencje, wyrażone w twierdzeniu drugim. W wypadku działań otwierających, mimo działania przypadku, można przypisać odpowiedzialność moralną, gdyż podmiot zachował częściową kontrolę, która jest warunkiem wpływu przypadku, aczkolwiek z racji działania samego przypadku i otwarcia działań podmiotu na wpływ przypadku nie można przypisać winy/zasługi moralnej, gdyż ta łączy się z intencją sprawcy. Traf okoliczności, skutku i przyczyny oddziałuje na przypisanie odpowiedzialności, ale tylko wówczas, gdy podmiot otworzył swoim działaniem bieg rzeczy na ów przypadek. Jeżeli takie otwarcie nie było do przewidzenia przez dany podmiot, to nie można przepisywać jemu odpowiedzialności.

Traf konstytutywny z kolei wpływa na zasoby moralne danej osoby. O ile jednak wpływ ten jest modyfikowalny, to dana osoba staje się moralnie odpowiedzialna za swoje zasoby moralne, dopiero gdy uzyska nad nimi kontrolę, tj. świadomość ich odziaływania i umiejętność zmiany owych zasobów. W tym, co niezmienialne w osobowości, traf konstytutywny tworzy jedynie zasoby moralne danej osoby. Tak jak pokazano, odnosząc się do uwag Andre, złe moralnie zasoby psychopaty nie czynią go przedmiotem oceny moralnej, $z$ tej racji, że są poza jego kontrolą.

Warto podkreślić, że autor artykułu uważa, iż traf wpływa w następujący sposób na moralność ludzką:

Po pierwsze, traf konstytutywny kształtuje osobowość i uposażenie moralne.

Po drugie, w kształtowaniu charakteru, możliwości zapobiegania przypadkom czy też posiadaniu wiedzy, jak zmienić własny charakter, olbrzymią rolę pełni traf epistemiczny. Podmiot nie ma całkowitej kontroli nad tym, czego się dowie na swój temat, na temat biegu rzeczy czy nawet tego, co jest moralnie złe, a co dobre. Tak więc traf poznawczy warunkuje moralne uposażenie podmiotu, jego wiedzę o świecie. Wpływ trafu nie oznacza, że przypisywanie 
odpowiedzialności i winy/zasługi moralnej jest nieuzasadnione. W tym zakresie, w jakim podmiot uzyskał autonomię i świadomość, a zatem kontrolę nad sobą i biegiem rzeczy, staje się odpowiedzialny moralnie.

Po trzecie, wpływ trafu okoliczności, skutku i przyczyny widoczny jest w przypisaniu odpowiedzialności moralnej, ale pod warunkiem zaistnienia działań otwierających danego podmiotu. Jak jednak pokazano, nie oznacza to wpływu trafu na przypisanie winy/zasługi moralnej. Nie oznacza też, że o przypisaniu odpowiedzialności decyduje sam przypadek.

Można więc stwierdzić, że zwolennicy trafu moralnego mają rację, mówiąc o wpływie trafu na odpowiedzialność moralną podmiotu za skutek nałożenia się na działania otwierające podmiotu przypadkowego ciągu przyczynowo-skutkowego. Nie mają jednak racji, mówiąc, że ocenianie owych działań łamie zasadę kontroli, ono ją zakłada. Autor artykułu stara się bronić zasadę kontroli jako podstawę przypisywania odpowiedzialności, winy/zasługi moralnej.

Przedstawione analizy pozwalają też stwierdzić, że problem trafu moralnego ujawnia nieprecyzyjność już stosowanych, a być może nawet brak, pojęć etycznych adekwatniej odnoszących się do ludzkiej kondycji. Rzeczywistość, a zwłaszcza przypadek, koincydencja zdarzeń powodują trudność w jednoznacznym przypisaniu odpowiedzialności i winy/zasługi moralnej. Autor artykułu uznaje, że skoro intencję należy brać pod uwagę tak samo jak skutek, to nie można przypisać winy moralnej w omawianych sytuacjach, o ile ktoś intencjonalnie nie chciał doprowadzić do danego (nie w pełni przypadkowego) skutku. Jednakże brak stosownej dystynkcji etycznej każe wprowadzić dosyć ryzykowną kategorię odpowiedzialności moralnej bez winy. Oddzielenie odpowiedzialności od winy sprzeciwia się bowiem powszechnemu w filozofii i intuicjach potocznych utożsamieniu winy z odpowiedzialnością moralną.

\section{A PROPOSAL TO SOLVE THE PROBLEM OF MORAL LUCK IN THE CONTEXT OF THE PRINCIPLE OF CONTROL}

\section{S UMMARY}

The article presents a proposal of solution of the problem of moral luck in the context of the principle of control. This principle states that the condition for assigning responsibility, moral guilt / merit is to have control over the action by the perpetrator. According to his supporters, a moral hit causes the moral evaluation of a subject's action that was disturbed by chance or a factor beyond the subject's control. The article tries to show that there is no complete lack of control in the actions that are affected by chance. Hence, one cannot 
put forward such distant consequences of the impact of luck on morality as the negation of the rationality of assigning moral responsibility and blame / merit in general. Instead, the article proposes to assign moral responsibility separately from guilt / merit, depending on the intention of the acting subject.

Keywords: moral luck, the principle of control, the paradox of moral luck, moral responsibility, intention, guilt

Slowa kluczowe: traf moralny, zasada kontroli, paradoks trafu moralnego, odpowiedzialność moralna, intencja, wina

\section{BIBLIOGRAFIA}

Adams R.M., Involuntary Sins, „The Philosophical Review” 94 (1985), s. 3-31.

Andre J., Nagel, Williams, and Moral Luck, w: Moral Luck, red. D. Statman, New York 1993, s. 123-129.

Filek J., Filozofia odpowiedzialności XX wieku, Kraków 2003.

Foley R., Epistemic Luck and the Purely Epistemic, „American Philosophical Quarterly” 21 (1988), s. 87-97.

Handbook of implicit social cognition: Measurement, theory, and applications, red. B. Payne, B. Gawronski, New York 2010.

Jensen H., Morality and Luck, w: D. Statman, Moral Luck, New York 1993, s. 131-140.

Kirkwood K.W., Of Luck Both Epistemic and Moral in Questions of Doping and Non-Doping, „Ethic in Progress” 11 (2020), nr 1, s. 77-84.

Krajewska A., Problem odpowiedzialności za przypadkowe skutki działań, „Roczniki Filozoficzne” LXVII (2019), nr 2, s. 119-140.

Moral Luck, red. D. Statman, New York 1993.

Nagel T., Traf w życiu moralnym, w: T. Nagel, Pytania ostateczne, thum. A. Romaniuk, Warszawa 1997, s. 37-53.

Nelkin D.K., Moral Luck, http://plato.stanford.edu/archives/win2013/entries/moral-luck/ [dostęp: 23.02.2016].

Ossowska M., Podstawy nauki o moralności, Wrocław-Warszawa-Kraków 1994.

Otsuka M., Moral Luck: Optional, Not Brute, „Philosophical Perspectives” 23 (2009), s. 373-388.

Payne B., Gawronski B., A history of implicit social cognition: Where is it coming from? Where is it now? Where is it going?, w: Handbook of implicit social cognition: Measurement, theory, and applications, red. B. Gawronski, B. Payne, New York 2010, s. 1-18.

Ravitch H., Knowledge and the Principle of Luck, „Philosophical Studies” 30 (1976), s. 347-349.

Rescher N., Moral Luck, w: Moral Luck, red. D. Statman, New York 1993, s. 141-166.

Richards N., Luck and Desert, w: Moral Luck, red. D. Statman, New York 1993, s. 167-180.

Schinkel A., The Problem of Moral Luck: An Argument Against its Epistemic Reduction, „Ethic Theory and moral Practice" 2009, nr 12, s. 267-277.

Statman D., Introduction..., w: Moral Luck, red. D. Statman, New York 1993, s. 1-34.

Strzyżyński P., Kilka uwag na marginesie sporu między Gregorym S. Kavką a Williamem Neblettem o poczucie winy, „Ruch Filozoficzny” 72 (2016), nr 2, s. 63-76.

Strzyżyński P., Wybrane konsekwencje trafu moralnego dla etyki, koncepcji społecznych i religijnych, „Teologia i Moralność” 26 (2019), s. 211-233.

Sverdlik S., Crime and Moral Luck, w: Moral Luck, red. D. Statman, New York 1993, s. 181-194. 
Tomasz z Akwinu, Suma teologiczna, thum. F.W. Bednarski, t. 18, Londyn 1970.

Weischedel W., Das Wesen der Verantwortung, Frankfurt am Main $1972^{3}$.

Williams B., Traf moralny, w: B. Williams, Ile wolności powinna mieć wola?, thum. T. Baszniak, T. Duliński, M. Szczubiałka, Warszawa 1999, s. 215-238.

Wolf S., The Moral of Moral Luck, „Philosophic Exchange” 31 (2001), s. 4-19.

Zimmerman M.J., Luck and Moral Responsibility, w: Moral Luck, red. D. Statman, New York 1993, s. $217-233$.

Zipursky B.C., Two dimensions of responsibility in crime, tort, and moral luck. „Theoretical Inquiries in Law" 9 (1), 2008, s. 97-137. 